\title{
The Gut Microbiota and Irritable Bowel Syndrome: Friend or Foe?
}

\author{
Uday C. Ghoshal, ${ }^{1}$ Ratnakar Shukla, ${ }^{2}$ Ujjala Ghoshal, ${ }^{2}$ Kok-Ann Gwee, ${ }^{3}$ \\ Siew C. Ng, and Eamonn M. M. Quigley ${ }^{5}$ \\ ${ }^{1}$ Department of Gastroenterology, Sanjay Gandhi Postgraduate Institute of Medical Science, Lucknow 226014, India \\ ${ }^{2}$ Department of Microbiology, Sanjay Gandhi Postgraduate Institute of Medical Science, Lucknow 226014, India \\ ${ }^{3}$ Stomach, Liver and Bowel Clinic, Gleneagles Hospital, Singapore \\ ${ }^{4}$ Department of Medicine and Therapeutics, Institute of Digestive Disease, Prince of Wales Hospital, \\ Chinese University of Hong Kong, Hong Kong \\ ${ }^{5}$ Department of Medicine, Alimentary Pharmabiotic Centre, University College Cork, Cork, Ireland
}

Correspondence should be addressed to Uday C. Ghoshal, udayghoshal@gmail.com

Received 15 November 2011; Accepted 7 January 2012

Academic Editor: Takanori Kanai

Copyright ( 2012 Uday C. Ghoshal et al. This is an open access article distributed under the Creative Commons Attribution License, which permits unrestricted use, distribution, and reproduction in any medium, provided the original work is properly cited.

Progress in the understanding of the pathophysiology of irritable bowel syndrome (IBS), once thought to be a purely psychosomatic disease, has advanced considerably and low-grade inflammation and changes in the gut microbiota now feature as potentially important. The human gut harbours a huge microbial ecosystem, which is equipped to perform a variety of functions such as digestion of food, metabolism of drugs, detoxification of toxic compounds, production of essential vitamins, prevention of attachment of pathogenic bacteria to the gut wall, and maintenance of homeostasis in the gastrointestinal tract. A subset of patients with IBS may have a quantitative increase in bacteria in the small bowel (small intestinal bacterial overgrowth). Qualitative changes in gut microbiota have also been associated with IBS. Targeting the gut microbiota using probiotics and antibiotics has emerged as a potentially effective approach to the treatment of this, hitherto enigmatic, functional bowel disorder. The gut microbiota in health, quantitative and qualitative microbiota changes, and therapeutic manipulations targeting the microbiota in patients with IBS are reviewed in this paper.

\section{Introduction}

Functional bowel disorders, including irritable bowel syndrome (IBS), are common gastrointestinal disorders all over the world. Previously, IBS was thought to be a psychosomatic disorder. However, in the last few decades, advances in our understanding of the pathophysiology of IBS have revealed several factors, including alterations in the microbiota, as potentially relevant to the cause of this syndrome and the precipitation of its symptoms. Indeed, alterations in the gut microbiota are being increasingly implicated in the pathogenesis of several gastrointestinal and systemic diseases. We wish, therefore, to review the gut microbiota and its alterations in, and relationships to, IBS.

\section{Gut Microbiota in Health}

The human gut harbours a huge microbial ecosystem, which is equipped to perform a variety of functions such as the digestion of food, metabolism of the drugs, detoxification of toxic compounds, production of essential vitamins, prevention of attachment of pathogenic bacteria to the gut wall and maintenance of homeostasis in the gastrointestinal tract (GIT) [1-3]. The human gut is first colonized at birth; this microbiota gradually increases in size and diversity up to the end of the first year of life; by that time, the gut microbiota has come to resemble that of the adult and remains relatively stable thereafter [4]. The composition of the gut microbiota varies according to age, sex, diet, geographical origin of the individual and is also influenced 
by certain environmental factors, such as administration of antibiotics [1]. The composition and activity of the human gut microbiota affect gastrointestinal and systemic homeostasis. There are 10 times more microbial cells $\left(10^{14}\right)$ in the gut than cells in the entire body $\left(10^{13}\right)$ [3]. A recent study has suggested that the human gut microbiota consists of more than 35,000 bacterial species and that $70 \%$ of all of microbes in the human body reside in the colon [4]. The small intestine consists of mainly Gram-positive and aerobic bacteria, whereas the large intestine consists largely of Gramnegative and strictly anaerobic bacteria $[5,6]$.

\section{Alteration of Gut Microbiota}

Alterations in the normal gut microbiota have been suggested as etiologic factors in the development of functional gastrointestinal disorders such as IBS and functional dyspepsia, common GI disorders of unknown etiology [7-9]. Quantitative alterations in the gut microbiota in the small bowel may result in the clinical syndrome recognized as small intestinal bacterial overgrowth (SIBO) [10]. In SIBO, such is the change in the number and type of bacteria in the upper small intestine that diarrhea, abdominal bloating, malabsorption, abdominal pain, and excessive gas production result; severe motor dysfunction may be an underlying cause [11-13].

Quantitative changes in the colonic microbiota may lead to the proliferation and development of specific species that produce more short-chain fatty acids (SCFAs) and gases, such as methane, hydrogen, and carbon dioxide, potentially resulting in abdominal bloating and distension. An increase in the concentration of SCFAs (acetate, butyrate, and propionate) leads to acidification of the colon and deconjugation of bile acid. This in turn may cause significant changes in water and electrolyte transport in the colon which result in diarrhea [8, 14, 15]. Malabsorption of carbohydrates may cause increased production of hydrogen gas, which is associated mainly with diarrhea-predominant IBS (IBS-D) [16] whilst excess methane gas production is associated with constipation-predominant IBS (IBS-C) [14].

\section{Irritable Bowel Syndrome}

IBS is a functional gastrointestinal disorder associated with abdominal discomfort or pain, distension and bloating, diarrhea, constipation, or mixed bowel habits (i.e., both constipation and diarrhea; IBS-M). IBS subjects may also experience greater levels of stress, anxiety, and depression compared to healthy subjects $[16,17]$. All of these co-morbidities are associated with impaired quality of life in IBS patients [18-20]. Several diagnostic criteria (Kruis, Manning, Rome) have been used to distinguish IBS patients from those with organic bowel disease in daily clinical practice $[11,21]$.

The prevalence of IBS varies from $9 \%$ to $22 \%$ in the United States and Europe [22, 23]. In Asian countries, IBS affects $4 \%$ to $20 \%$ of populations. In Asia, the lowest prevalence has been reported from India, at $4.2 \%$, and the highest from Japan and Singapore [23-25].
The exact etiology and pathophysiology of IBS remain unclear. Several hypotheses have been proposed which include alteration in the gut microbiota, dysregulation of the brain-gut axis and autonomic nervous system, visceral hypersensitivity, and altered levels of gastrointestinal neuropeptides and hormones $[11,22,26]$. Furthermore, abnormal gastrointestinal motility, as well as genetic, environmental, and psychological factors, may also play important roles in the development of IBS. Recent studies have also shown that IBS is associated with low-grade intestinal inflammation resulting from an activated immune system, in response to a normal or abnormal gut microbiota $[1,27,28]$.

\section{Pathophysiology}

5.1. Altered Gut Microbiota or Dysbiosis. There is a growing interest in investigating the role of an altered gut microbiota in the pathogenesis of IBS [14, 29]. Normal gut microbiota have either direct bactericidal effects or can prevent the adherence of pathogenic bacteria to the wall of the gastrointestinal tract $[7,30,31]$. Dysbiosis in the gut may facilitate the adhesion of enteric pathogens in the human gut which can be associated with IBS symptoms [30, 32]. Alteration in the composition of the normal microbiota and disturbed colonic fermentation in IBS patients may play an important role in development of IBS symptoms [33]. Firmicutes and Bacteroidetes are the major beneficial gut microbiota in the normal human and changes in their relative numbers have been reported in IBS patients [1]. Significantly, a two-fold increase in the ratio of Firmicutes to Bacteroidetes has been reported in IBS patients. This results from an increase in the quantity of Ruminococcus, Clostridium, Dorea species and a decrease in the quantity of Bifidobacterium and Faecalibacterium species [34]. Significantly greater abundance of classes of Gammaproteobacteria and Enterobacteriaceae in healthy controls were positively correlated with the inflammatory markers IL-6 and IL-8. Higher levels of these cytokines have been reported in IBS patients $[34,35]$. Due to a different microenvironment in the intestinal epithelium and lumen, the composition of microbiota is not the same at the level of the gut epithelium and lumen [33]. Culture-based analysis had shown that there were significant differences between the mucosa-associated microbiota and fecal samples in both healthy control and IBS patients. For example, a significantly increased quantity of aerobic bacteria and Lactobacillus was noted in IBS-D in feces but not in mucosal samples [19].

Several studies using different methodologies to define changes in the microbiota have been published, including classic culture-based techniques, PCR-based molecular technologies such as real-time PCR (q PCR), microarray, DGGE (denaturation gradient gel electrophoresis), GC profiling, and high-throughput sequencing based on $16 \mathrm{~s}$ rRNA $[33,36]$ (see Table 1).

Bacterial fermentation of undigested, unabsorbed food causes production of SCFAs, which are bacteriostatic for a group of species, either directly or by reducing $\mathrm{pH}[2,7,30$, $31,37]$. SIBO causes unusual fermentation with increases in gas production and abnormal gastrointestinal motility. A 
TABLE 1: Summary of the studies on the alteration in gut microbiota in IBS subjects.

\begin{tabular}{|c|c|c|c|c|c|c|}
\hline S. No. & $\operatorname{IBS}(n)$ & $\begin{array}{l}\text { Healthy } \\
(n)\end{array}$ & $\begin{array}{l}\text { Diagnostic } \\
\text { criteria }\end{array}$ & Method & Outcome & Reference \\
\hline 1 & 11 & 8 & Rome II & PCR and DGGE & $\begin{array}{l}\text { Diversity of total bacteria } \\
\text { along with Lacto bacillus was } \\
\text { higher in IBS patients than } \\
\text { healthy control }\end{array}$ & Ponnusamy et al. [1] \\
\hline 2 & 24 & 23 & Rome II & $\begin{array}{l}\text { Nucleic acid } \\
\text { fractionation according } \\
\text { to GC content, cloning } \\
\text { followed by sequencing } \\
\text { and qPCR }\end{array}$ & $\begin{array}{l}\text { Collinsella aerofaciens, } \\
\text { Clostridium cocleatum, and } \\
\text { Coprococcus eutactus } \\
\text { confirmed significant } \\
\text { difference from that of healthy } \\
\text { subjects }\end{array}$ & Kassinen et al. [18] \\
\hline 3 & 10 & 10 & Rome III & Culture and q PCR & $\begin{array}{l}\text { Significantly decreased } \\
\text { quantity of aerobic bacteria in } \\
\text { IBS than healthy control and } \\
\text { increased concentration of } \\
\text { Lactobacillus species in D-IBS } \\
\text { patients than healthy control }\end{array}$ & Carroll et al. [19] \\
\hline 4 & 37 & 20 & Rome II & DGGE and $\mathrm{q}$ PCR & $\begin{array}{l}\text { Significant increase in the } \\
\text { amount of Pseudomonas } \\
\text { aeruginosa in IBS patients }\end{array}$ & Kerckhoffs et al. [33] \\
\hline 5 & 16 & 16 & Rome II & $\begin{array}{l}\text { RT-PCR-DGGE, } \\
\text { Transcript analysis with } \\
\text { the aid of affinity } \\
\text { capture (TRAC) }\end{array}$ & $\begin{array}{l}\text { Significantly decreased } \\
\text { amount Clostridium } \\
\text { coccoides-E. rectale in IBS-C }\end{array}$ & Maukonen et al. [106] \\
\hline 6 & 41 & 26 & Rome II & FISH Analysis & $\begin{array}{l}\text { Significantly decreased } \\
\text { quantity of Bifidobacterium } \\
\text { catenulatum in faecal and } \\
\text { duodenal samples of IBS } \\
\text { patients than healthy control }\end{array}$ & Kerckhoffs et al. [107] \\
\hline 7 & 44 & 34 & Rome II & Culture and PCR & $\begin{array}{l}\text { Significantly increased } \\
\text { quantity of Enteraggroegative } \\
\text { Escherichia coli in IBS-D }\end{array}$ & $\begin{array}{c}\text { Sobieszczańska et al. } \\
{[108]}\end{array}$ \\
\hline 8 & 20 & 15 & Rome II & q PCR & $\begin{array}{l}\text { Decreased quantity of } \\
\text { Clostridium thermosuccinogens } \\
\text { in IBS-D patients and } \\
\text { increased quantity of } \\
\text { Ruminococcus torque in IBS-D } \\
\text { patients than healthy control. } \\
\text { Ruminococcus bromii was } \\
\text { more abundant in IBS-C than } \\
\text { healthy control }\end{array}$ & Lyra et al. [109] \\
\hline 9 & 12 & 22 & Rome II & $\begin{array}{l}\% \mathrm{G}+\mathrm{C} \text { profiling and } \\
\text { fractioned DNA } \\
\text { sequencing followed by } \\
\mathrm{q} \text { PCR }\end{array}$ & $\begin{array}{l}\text { Significantly increased } \\
\text { quantity of Proteobacteria and } \\
\text { Firmicutes and reduced } \\
\text { quantity of Actinobacteria and } \\
\text { Bacteroidetes in IBS-D patients } \\
\text { than healthy control }\end{array}$ & $\begin{array}{c}\text { Krogius-Kurikka et al. } \\
{[110]}\end{array}$ \\
\hline 10 & 25 & 25 & Rome II & Culture & $\begin{array}{l}\text { Significantly reduced number } \\
\text { of Bifidobacterium and } \\
\text { increased number of } \\
\text { Enterobacteriaceae in IBS } \\
\text { patients than healthy control }\end{array}$ & Si et al. [111] \\
\hline
\end{tabular}


TABle 1: Continued.

\begin{tabular}{|c|c|c|c|c|c|c|}
\hline S. No. & $\operatorname{IBS}(n)$ & $\begin{array}{l}\text { Healthy } \\
(n)\end{array}$ & $\begin{array}{c}\text { Diagnostic } \\
\text { criteria }\end{array}$ & Method & Outcome & Reference \\
\hline 11 & 47 & 33 & Rome II & DGGE of $16 \mathrm{~S}$ rRNA & $\begin{array}{l}\text { Significant difference in gut } \\
\text { microbiota in IBS patients and } \\
\text { healthy control along with } \\
\text { more variation in the gut } \\
\text { microbiota in control than } \\
\text { IBS subjects }\end{array}$ & Codling et al. [112] \\
\hline 12 & 26 & 26 & Rome II & Culture and q PCR & $\begin{array}{l}\text { Significantly increased } \\
\text { quantity of Lactobacillus and } \\
\text { Veillonella in IBS patients than } \\
\text { control }\end{array}$ & Tana et al. [113] \\
\hline 13 & 10 & 10 & Rome III & $\begin{array}{l}\text { PCR and } \\
\text { Pyrosequencing }\end{array}$ & $\begin{array}{l}\text { Significantly increased } \\
\text { number of Bacteroidetes and } \\
\text { Synergistetes and reduced } \\
\text { number of Actinobacteria, } \\
\text { Bacilli, Flavobacteria, and } \\
\text { Epsilonproteobacteria in IBS } \\
\text { than control }\end{array}$ & $\mathrm{Ng}$ et al. [114] \\
\hline 14 & 22 & 22 & Rome III & $\begin{array}{l}\text { Metagenomics of } 16 S \\
\text { rRNA gene followed by } \\
\text { PhyloChip hybridization } \\
\text { and Pyrosequencing }\end{array}$ & $\begin{array}{l}\text { Significantly greater } \\
\text { abundance of class } \\
\gamma \text {-Proteobacteria in IBS } \\
\text { children than healthy control } \\
\text { and Haemophilus } \\
\text { parainfluenzae was prominent }\end{array}$ & Saulnier et al. [35] \\
\hline 15 & 62 & 46 & Rome II & q PCR and microarray & $\begin{array}{l}\text { Significantly } 2 \text {-fold increased } \\
\text { ratio of Firmicutes to } \\
\text { Bacteroidetes in IBS patients } \\
\text { comparison with the healthy } \\
\text { control }\end{array}$ & $\begin{array}{c}\text { Rajilić-Stojanović et } \\
\text { al. [34] }\end{array}$ \\
\hline
\end{tabular}

IBS: irritable bowel syndrome; IBS-D: diarrhea predominant IBS; IBS-C: constipation predominant IBS; PCR: polymerase chain reaction; DGGE: denaturation gradient gel electrophoresis; q PCR: real time PCR; FISH: fluorescent in situ hybridization; TRAC: transcript analysis with the aid of affinity capture.

previous study reported that the prevalence of SIBO in IBS subjects detected by lactulose hydrogen breath test was about $78 \%$ [14]. However, this study used the lactulose hydrogen breath test which has now been shown to be prone to a high rate of false positive result [38] and may have led to an overestimation of its frequency.

5.2. Postinfectious IBS (PI-IBS). IBS develops in a subgroup of individuals following an episode of acute gastrointestinal infection, known as PI-IBS. Acute enteric infections are characterized by abdominal discomfort, fever, vomiting, bloating, and diarrhea, $[14,39,40]$. Fever and vomiting generally improve after a few days while abdominal discomfort, diarrhea and bloating "persist" in those who develop PIIBS [39]. Risk factors for the development of PI-IBS include younger age, female gender, prolonged duration of diarrhea, the presence of bacterial pathogens, and psychological morbidities including anxiety, frustration, and depression [41-43].

The risk of IBS increased sixfold after an acute gastrointestinal infection and persists for up to 3 years $[44,45]$. Recent studies have shown that PI-IBS develops in 3-30\% of individuals with bacterial gastroenteritis caused by a number of enteric pathogens such as Campylobacter species, Clostridium perfringens, Staphylococcus aureus, Bacillus cereus, Shigella and viruses [7, 30, 32, 39].

The prevalence of PI-IBS in subjects who had suffered from diarrhea whilst travelling in developing countries has been estimated to be $7-14 \%$ [46]. The diagnosis of PIIBS was made according to Rome criteria for IBS among individuals who did not have IBS previously but developed it after the episode of acute gastroenteritis [14, 39]. Recent studies have suggested that PI-IBS is associated with dysbiosis in the gut (induced either by enteric infection or by the use of antibiotics), psychological factors (such as stress, anxiety, and depression), genetic susceptibility of the host, persistent activation of the host immune system, increased intestinal permeability, and an increased number of enterochromaffin cells in the gut $[22,39,47]$.

Potentially harmful microorganisms and their metabolites cause the disruption of tight junctions between epithelial cells leading to increased mucosal permeability during the acute phase of infection $[48,49]$. The permeability of the proximal small intestine in PI-IBS was shown to 
besignificantly increased compared to controls [50]. Zona occludens (ZO-1) are tight junction protein that link the transmembrane domain. A lesser expression of ZO-1 has been observed in biopsy samples of IBS subjects [51].

As a result of increased permeability of intestinal epithelial cells, an influx of immune cells including mast cells, $\mathrm{T}$ lymphocytes, macrophages, and inflammatory mediators such as IL-2, IL-1 $\beta$, IL-6, IL10, TGF- $\beta$ occurs after an acute enteric infection $[48,49,52,53]$. A growing body of evidence indicates that mast cells and lymphocytes are increased in the mucosa of both PI-IBS and IBS patients [54]. T lymphocytes are significantly increased in PI-IBS compared with control subjects [52]. IL-1 $\beta$ is significantly increased in PI-IBS patients during and after the infection compared with those subjects who do not develop PI-IBS [53]. Certain cytokines such as IL-6 may also further change gut permeability. Increased levels of IL-6 have been reported in IBS subjects compared with healthy controls [49]. These inflammatory mediators (IL- $1 \alpha$, IL- $1 \beta$, IL-6, IFN- $\gamma$ ) damage the intestinal epithelial barrier and cause inflammation [48]. Furthermore, the administration of antibiotics altered the composition of the gut microbiota and inhibited the expression of antimicrobial peptide Reg III $\gamma$ produced by commensal bacteria. Reg III $\gamma$ strengthens the intestinal epithelial barrier by inhibiting Gram-negative pathogens but has no effect on Gram-positive bacteria; its inhibition results, therefore, in a favourable environment for enteric pathogens to proliferate $[4,7,55]$.

5.3. Small Intestinal Bacterial Overgrowth (SIBO). Normally, the density of bacteria is much lower in the small intestine than in the large intestine. There are $10^{10-12}$ colonyforming units (cfu) per $\mathrm{mL}, 10^{5-8} \mathrm{cfu} / \mathrm{mL}, 10^{0-5} \mathrm{cfu} / \mathrm{mL}$ and $10^{0-4} \mathrm{cfu} / \mathrm{mL}$ bacteria in the cecum, terminal ileum, proximal ileum, and jejunum/duodenum, respectively $[54,56]$. The major families of bacteria in the small intestine include Bacilli, Streptococcaceae, Actinobacteria, Actinomycinaea, and Corynebacteriaceae [4]. Qualitative or quantitative changes in the microbiota of small intestine may lead to the clinical features of SIBO $[56,57]$. In healthy individuals, the normal bacterial count in the proximal small intestine is $\leq 10^{4} \mathrm{cfu} / \mathrm{mL}$; SIBO is traditionally defined by a bacterial count of $\geq 10^{5} \mathrm{cfu}$ per $\mathrm{mL}$ in jejunal aspirate $[2,56]$. Several techniques have been used for the diagnosis of SIBO, which include the lactulose hydrogen (LHBT), ${ }^{14} \mathrm{C}$ xylose and glucose hydrogen (GHBT) breath tests and culture of jejunal aspirate $[13,56,58]$. Hydrogen and methane are normally produced in the large intestine but in case of SIBO these gases are produced in the small bowel also [13]. Methanobrevibacter smithii, Methanobrevibacter stadtmanae, and, possibly, Coliform bacteria produce methane gas $[13,14]$.

The jejunal aspirate culture has, traditionally, been used as the gold standard to diagnose SIBO. The limitations of this test however include invasiveness and the challenges posed by attempting to culture all strains and species [54, 57]; therefore, hydrogen breath tests (GHBT or LHBT) are most commonly used [59]. In a study where endoscopic jejunal biopsy culture was used to diagnose SIBO, its sensitivity and specificity were $83.5 \%$ and $97.2 \%$, respectively [60]. The prevalence of SIBO in IBS patients was $4 \%$ (based on the definition of $\geq 10^{5} \mathrm{cfu} / \mathrm{mL}$ of bacteria in jejunal aspirate) and no different from that seen in healthy individuals [56]. In contrast, in a study of 111 IBS subjects using LHBT, Pimentel et al. reported a prevalence of SIBO of $84 \%$ in IBS (in comparison to $20 \%$ in healthy individuals). Furthermore, the administration of neomycin significantly alleviated IBS symptoms [61]. Recent published data have shown that, using jejunal aspirate as the gold standard, double-peak in LHBT only diagnoses one-third of SIBO patients; the sensitivity and specificity of LHBT were $31 \%$ and $86 \%$ and those of GHBT were $44 \%$ and $80 \%$, respectively [62]. In a separate study by Berthold, the sensitivity and specificity of lactose-(13C) ureide breath test (LUBT) were $66.7 \%$ and $100 \%$ and those of GHBT $41.7 \%$ and $44.4 \%$, respectively [63]. The sensitivity and specificity after glucose were $62.5 \%$ and $82 \%$ and after lactulose were $52 \%$ and $86 \%$, respectively [13]. The variation in LHBT and GHBT may be due to differences in the diagnostic criteria used for selection of IBS patients, ecological origin, nature of the substrate used, and diagnostic methods [59].

The administration of antibiotics and probiotics reduced not only gas-related problems but also IBS-like symptoms $[54,56,61,64]$. SIBO may arise due to hypochlorhydria, altered intestinal motility $[2,56]$, altered bacteriostatic properties of pancreatic and biliary secretion [65], and a dysregulated immune response [2]. Proton pump inhibitors (PPIs) may predispose to SIBO by decreasing acid secretion in the stomach [66]. Theisen reported that the inhibition of acid secretion related to the administration of omeprazole led to an increased concentration of unconjugated bile acids. Deconjugation of bile acids inhibits the absorption of fat and lipid soluble vitamins [67]. Thus, the potential side effects of PPI include constipation, diarrhea, bloating, and abdominal pain, symptoms which resemble those of IBS [68] (see Table 2).

5.4. Intestinal Barrier Dysfunction and Altered Immune Response. Commensal bacteria provide a favourable environment, prevent the adherence of pathogenic bacteria, and modulate innate and adaptive immune responses $[55,69]$. They also protect the intestinal epithelial cell (IEC) from an inflammatory response. The intestinal epithelium contains a large number of lymphocytes that can remove infected epithelial cells [70].

Paneth cells found at the base of the intestinal gland (crypt of Lieberkuhn) throughout the small intestine can prevent the penetration of intestinal epithelium by commensal and pathogenic bacteria [71]. IECs are protected by a glycocalyx layer of mucus, the epithelial junction adhesion complex, secretory IgA, chloride secretion, and other glycoproteins $[30,55]$. The intestinal barrier consists of the tight junction complex, adherin junctions, gap junctions, and desmosomes. There are more than 40 types of proteins in the tight junction complex, which play crucial role in maintaining the permeability of the intestinal epithelium [72]. A leaky intestinal epithelium has been reported in subjects 


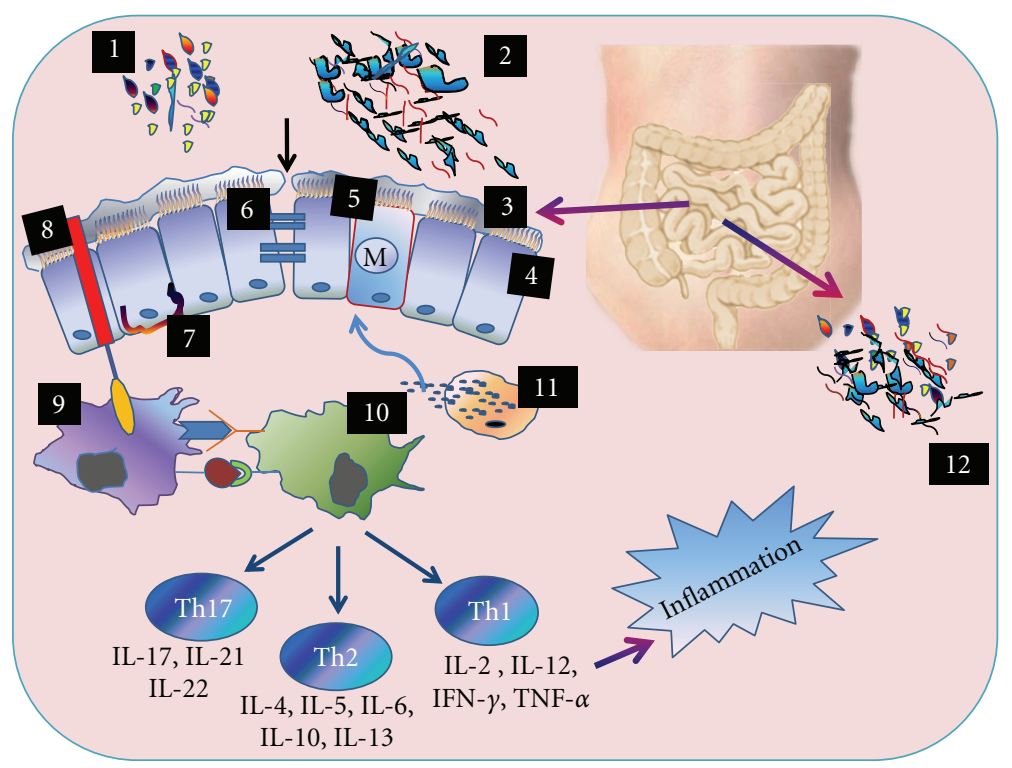

Figure 1: (1) Commensal bacteria (2) Pathogenic bacteria (3) Mucus layer (4) Intestinal epithelium (5) Peyer's patch (6) Tight junction protein (7) Paneth cell (8) Toll-like receptors (9) Dendritic cell (10) T cell (11) Degranulation of mast cells (12) Small intestinal bacterial overgrowth. The intestinal microbes may form a natural barrier to pathogenic bacteria. Therefore, any qualitative or quantitative change in the gut microbiota leads to the instability of the gut microbial ecosystem. It facilitates the entry of pathogenic bacteria and allows them to adhere to the wall of the intestinal epithelial cell. Degranulation of mast cells releases substances that increase the permeability of mucosa resulting in a reduction in the integrity of the tight junctional protein complex. Luminal bacteria or bacterial products such as peptidoglycans and lipopolysaccharides interact with Toll-like receptors on dendritic cells and macrophages. After processing, these cells present the antigen to T cells leading to the production of cytokines, chemokines which cause inflammation in the gastrointestinal tract. Paneth cells are found throughout the small intestine and secrete alpha defensins and lysozyme which, not only eliminate pathogenic bacteria, but also maintain the integrity of the intestinal membrane. Lymphocytes are found in a more organized structure called lymphoid follicles. M cells play an important role in transporting bacteria and microbial particles from the lumen to the lymphoid follicles. The areas around M cells, called Peyer's patches, facilitate the mucosal immune response.

with IBS, ulcerative colitis, Crohn's disease, celiac disease, and food-borne infections [72-75]. A recent study has shown that MicroRNA-29a regulates the permeability of the intestine through the generation of glutamine synthetase in patients with IBS. Glutamine synthetase controls the concentration of glutamine. Decreased concentration of glutamine leads to an increase in the permeability of intestinal epithelial cells (IEC), whilst the permeability of IECs can be recovered by the supplementation of glutamine in patients with IBS [75]. The administration of probiotics, fermented milk (Streptococcus thermophilus, Lactobacillus bulagaris Lactobacillus acidophilus, and Bifidobacterium longum) and L. plantarum has been shown to strengthen the intestinal barrier [72-74]. Paneth cells and enterocytes in the gut secrete antimicrobial molecules such as angiogenin 4, defensins, IgA antibodies, and RegIII $\gamma$. These antimicrobial peptides destroy pathogenic bacteria by forming a pore in the bacterial cell wall $[7,55,76]$. These data suggest that a symbiotic relationship is present between commensal bacteria and the host.

The composition of the gut microbiota influences the development of the immune system. Any alterations in the gut microbiota due to enteric infections, antibiotic therapy or acid suppressive treatment lead to activation of both the innate and adaptive immune responses [69]. Certain commensal bacteria induce intestinal inflammation while others regulate the immune response. Commensal bacteria from the phylum of Bacteroidetes and Firmicutes have been shown to induce $\mathrm{T}$ regulatory cells and inhibit Th17mediated inflammation. In contrast, the administration of Bifidobacterium animalis subspecies inhibited intestinal inflammation via a reduction of the commensal bacteria Enterobacteriace [55, 77, 78].

Thus, the gut microbiota plays an important role in the maintenance of homeostasis of various subpopulations of $\mathrm{T}$ cells: regulatory $\mathrm{T}$ cells (Tregs), $\mathrm{T}$ helper 1 (Th1), and $\mathrm{T} 17$ (Th17) cells in the gut [79]. Low-grade inflammation in the intestine in IBS patients is associated with the activation of $\mathrm{T}$ lymphocytes and mast cells, increased expression of proinflammatory cytokines such as IL-6 and IL-8, and elevated levels of IL- $1 \beta$, TNF- $\alpha$, and IL- 8 in peripheral blood mononuclear cells $[80,81]$. Significantly increased levels of TNF- $\alpha$, IL- $1 \beta$, and IL- 6 , stimulated by lipopolysaccharide (LPS), have been reported in an IBS-D subgroup while increased levels of LPS-stimulated IL- $1 \beta$ were described in an IBS-C subgroup (Figure 1).

In PI-IBS, LPS-induced cytokines (TNF- $\alpha$, IL- $1 \beta$, and IL-6) are significantly increased when compared with controls. IL-1 $\beta$ causes alteration in secretomotor function during inflammation [80]. Increased concentrations of IL- $1 \beta$ are associated with the development of IBS symptoms such as alteration in bowel habits [81]. Elevated levels of IL-6 are 
TABLE 2: Summary of prevalence of SIBO in IBS patients by different diagnostic methods.

\begin{tabular}{|c|c|c|c|c|c|}
\hline Diagnostic method & $\begin{array}{l}\text { N. of IBS } \\
\text { patients }\end{array}$ & $\begin{array}{c}\text { N. of } \\
\text { controls }\end{array}$ & $\begin{array}{l}\text { Percentage of } \\
\text { SIBO in IBS } \\
\text { subjects }\end{array}$ & $\begin{array}{l}\text { Percentage of } \\
\text { SIBO in } \\
\text { controls }\end{array}$ & Reference \\
\hline LHBT & 76 & 40 & $44.7 \%$ & $40.0 \%$ & Park et al. [115] \\
\hline LHBT & 43 & 56 & $65 \%$ & $7 \%$ & Scarpellini et al. [116] \\
\hline LHBT & 127 & - & $43 \%$ & - & Carrara et al. [5] \\
\hline LHBT & 258 & - & $34.5 \%$ & - & $\begin{array}{c}\text { Mann and } \\
\text { Limoges-Gonzales } \\
{[117]}\end{array}$ \\
\hline LHBT & 98 & - & $65 \%$ & - & $\begin{array}{c}\text { Nucera et al. } \\
\text { Lombardolll [118] }\end{array}$ \\
\hline GHBT & 59 & 37 & $23.7 \%$ & $2.7 \%$ & Sachdeva et al. [119] \\
\hline GHBT & 98 & - & $36 \%$ & - & $\begin{array}{c}\text { Reddymasu et al. } \\
{[120]}\end{array}$ \\
\hline GHBT & 200 & 50 & $24.5 \%$ & $6 \%$ & Lombardo et al. \\
\hline GHBT & 1921 & - & $31 \%$ & - & Ford et al. [121] \\
\hline GHBT & 130 & 70 & $16.1 \%$ & $4.2 \%$ & Parodi et al. [122] \\
\hline GHBT & 225 & 100 & $11.1 \%$ & $1 \%$ & Rana et al. [123] \\
\hline GHBT & 204 & - & $46 \%$ & - & Majewski et al. [124] \\
\hline GHBT & 96 & - & $45.8 \%$ & - & $\begin{array}{c}\text { Cuoco and } \\
\text { Salvangnini [125] }\end{array}$ \\
\hline GHBT & 65 & 102 & $31 \%$ & $4 \%$ & Lupascu et al. [126] \\
\hline GHBT & 129 & 51 & $8.5 \%$ & $2 \%$ & Ghoshal et al. [58] \\
\hline Hydrogen & 158 & 34 & $32.9 \%$ & $17.9 \%$ & Grover et al. [127] \\
\hline $\begin{array}{l}\text { Breath test and culture } \\
\text { of small bowel aspirate }\end{array}$ & 162 & 26 & $4 \%$ & $4 \%$ & Posserud et al. [56] \\
\hline
\end{tabular}

Abbreviations used: SIBO: small intestinal bacterial overgrowth; IBS: irritable bowel syndrome; LHBT: lactulose hydrogen breath test; GHBT: glucose hydrogen breath test.

produced during stress, inflammation, and infectious disease [82]. Thymus-derived T regulatory cells (Treg) are involved in the suppression of inflammation in IBS, ulcerative colitis, and Crohn's disease through the inhibition of T effector cells. It has been shown that $\mathrm{T}$ cells express high levels of CD25 Tregs in the colon in IBS patients. Therefore, any alteration in the frequency of Tregs may lead to recruitment of immune effectors which, consequently, results in inflammation [83, 84].

Intestinal epithelial cells recognize pathogens by way of pattern recognition receptors including Toll-like receptors (TLRs) and nucleotide-oligomerization-domain-(NOD) like receptors. They induce innate immune responses by the transcription and translation of antimicrobial proteins and the induction of proinflammatory cytokines and chemokines through the NF- $\kappa \mathrm{B}$ pathway $[30,70]$. Ten TLRs have been reported in man so far, which recognized various microbial pathogens, including viruses, bacteria, fungi, and protozoa. A recent study has reported upregulation of TLR 4 and TLR 5 and down-regulation of TLR 7 and TLR 8 in IBS patients [28]. Increased levels of TLR 4 and TLR 5 indicate that their cognate ligands, LPS and flagellin, are also increased in IBS patients. Since the ligand for TLR 7 and TLR 8 is singlestranded RNA, decreased level of TLR 7/8 suggested that viral infection may also play an important role in the development of IBS-like symptoms. Such infections have been reported in relation to the development of PI-IBS. These data further support that increased permeability is present in at least a subgroup of IBS patients $[28,85]$.

$\beta$-defensin 2 is an antimicrobial protein secreted by intestinal epithelial cells and induced by TLR 4 . Increased levels of $\beta$-defensin 2 have been reported in the intestine of patients with either IBS or ulcerative colitis $[84,85]$. Several studies have shown that commensal bacteria may reduce inflammation, in part, by directly acting on dendritic cells to stimulate the induction of IL-10 and regulatory T cells (Treg). With an increase in the number of commensal bacteria, dendritic cells provide signals to lymph nodes to stimulate adaptive immune responses leading to induction of IgA antibodies that wrap the luminal antigens and, thus, prevent them from breaching the intestinal barrier and the inhibition of the systemic immune response. Dendritic cells can directly sample luminal pathogens without disruption of tight junctions [30, 55, 86]. Degranulation of mast cells releases histamine and other potent mediators that can influence the function of the enteric nervous system and smooth muscles, causing IBS-like symptoms [30]. In addition, a study has shown that mast cells are significantly increased in the caecum in patients with IBS [87]. Tryptase, a protease released by mast cells, has been reported to be 
significantly increased in the colonic mucosa of patients with IBS. Increased concentrations of serine protease have been reported in the stool of IBS subjects $[30,84]$.

\subsection{Targeting the Microbiota}

5.5.1. Probiotics. The observation of dysbiosis in the gut microbiota, altered mucosal barrier function, activated immune responses, and SIBO support a role for bacteria in the pathogenesis of IBS [88]. Probiotics are live or attenuated microorganisms which, when administered in sufficient quantities, have been shown to improve gut epithelial integrity, as well as alleviate the symptoms of IBS [30, 8890]. Previous studies have shown that the administration of adequate amounts of probiotics (live microorganisms) may alleviate the symptoms of IBS, suppress proinflammatory cytokines, and promote the integrity of the intestinal barrier $[3,31]$. One study showed that the consumption of Bifidobacterium infantis 35624 was associated with proliferation of $\mathrm{T}$ regulatory cells, reduction of proinflammatory cytokines, down regulation of $\mathrm{T}$ cells, reduced expression of co-stimulatory molecules, and attenuation of NF- $\kappa \mathrm{B}$ [86]. In vitro, increased levels of proinflammatory cytokines (IL-12) and decreased concentrations of the anti-inflammatory cytokine (IL-10) by PBMCs have been reported in IBS patients. The ratio of IL-10/IL-12 was altered in IBS patients compared to healthy volunteers and the administration of Bifidobacterium infantis normalised this ratio [90]. Probiotics also inhibit adhesion of enteric pathogens to the wall of the gastrointestinal tract [30].

Probiotics should have the following characteristics: (1) they must survive in the gastrointestinal tract following passage and eventually reside in the colon, (2) they must not have a major adverse effect on other beneficial bacteria in the gut, (3) they should be hostile to mutagenic or pathogenic organisms in the gut, and (4) they must be stable genetically [91]. In clinical studies, probiotics have been shown to improve infectious or secretory diarrhea, traveller's diarrhea, and antibiotic-induced diarrhea via a number of mechanisms that may include direct effects on gastrointestinal motility and the enteric nervous system [30]. In a separate study, patients with IBS were treated with Bifidobacterium infantis or Lactobacillus salivarius (1E10) in malted milk or malted milk alone (as a placebo) for 8 weeks; there was a significant reduction in abdominal pain, discomfort, bloating, distension, and bowel movement difficulty in patients who received Bifidobacterium infantis compared with those who had placebo [90].

The use of multispecies probiotics has shown favorable effects in improving symptoms of IBS. VSL\#3 contains a mixture of different bacterial species including Lactobacillus species (L. casei, L. plantarum, L. acidophilus, and L. delbrueckii), Bifidobacterium species (B. longum, B. breve, and B. infantis), and Streptococcus thermophilus. A randomized controlled trial showed that the oral administration of VSL\#3, twice daily for 8 weeks, significantly reduced abdominal bloating, but not other parameters (colonic transit time, bowel dysfunction, abdominal pain, flatulence, or urgency) in a subgroup of diarrhea predominant IBS patients, when compared with placebo [92]. In a second study targeting 48 IBS patients with bloating, VSL\#3 significantly reduced flatulence and colonic transit compared with the placebo group [93].

In summary, many clinical trials have investigated the therapeutic benefits of probiotics in patients with IBS. However, differences in duration of therapy, heterogeneity in species or strains of selected bacteria, and differences in characteristics of the enrolled patients have resulted in inconsistent results.

5.5.2. Prebiotics. Prebiotics are nondigestible dietary supplements that affect the host by stimulating the growth of beneficial bacteria in the colon. Prebiotics have the capability to stimulate only microbes which are already residing in the gut [94]. Prebiotics are fermented by host bacteria and have been associated with a reduction in the level of triglyceride, improvement of the postprandial glucose level and a reduction in intestinal permeability $[3,95]$. The fermentation of prebiotics leads to the production of SCFAs such as butyric acids, which can serve as energy source for intestinal epithelial cells [94]. When galactooligosaccharides are used as prebiotics, they are known to stimulate gut bifidobacteria in IBS patients and, thereby, reduce the symptoms of IBS [96]. A potential limitation of prebiotic treatment is that prebiotics undergo fermentation and could produce bloating and flatulence [97].

5.5.3. Synbiotics. Synbiotics are defined as a combination of probiotics and prebiotics [98]. One study has shown that a combination of Bifidobacterium spp. and a prebiotic, inulin, significantly increased the quantity of Bifidobacteria. Furthermore, prebiotics also help passage of probiotics through the upper gastrointestinal tract and facilitate their establishment in the colon [91]. However, data on synbiotics in various gastrointestinal diseases including IBS is scanty.

5.5.4. Prokinetics. Prokinetic drugs increase gastrointestinal motility. As impaired gut motility is associated with dysbiosis and SIBO, prokinetics could benefit IBS patients through an effect on the microbiota [99]. However, studies reporting the use of erythromycin for the treatment of IBS have shown limited efficacy [100]. Furthermore, domperidone and cisapride were not always effective for the treatment of IBS. In any event, cisapride has been withdrawn from the market due to adverse cardiac effect [101].

5.5.5. Antibiotics. As discussed in previous sections, accumulating data support the role of bacteria in the etiology of IBS [102-104], and studies using antibiotics to target the intestinal microbiota to treat IBS are now emerging. In a double blind, randomized placebo-controlled study, neomycin was more effective than placebo in reducing IBS symptoms. However, the use of neomycin in the treatment of IBS has been limited by a marginal degree of efficacy above placebo and side effects [61]. 
Rifaximin, derived from rifamycin, is highly concentrated in the gut lumen and has little systemic absorption. It has been used in the treatment of traveller's diarrhea and SIBO. In a recent, large, double-blind, placebo-controlled trial, in which subjects were administered $550 \mathrm{mg}$ rifaximin 3 times daily for 2 weeks and followed up for 10 weeks, there was a significant reduction in global IBS symptoms in the rifaximin group in comparison to placebo (40.8\% versus $31.2 \%$ ). In addition, there was a significantly greater reduction in bloating in those who received rifaximin compared to placebo $(40.2 \%$ versus $30.3 \%)$ [89, 103, 105].

A combination of probiotics and antibiotics may play a beneficial role in the treatment of IBS symptoms [3]. Probiotics may increase the efficiency of antibiotics and reduce gastrointestinal pathogens by the production of antibacterial molecules including bacteriocins [3].

\section{Summary and Conclusions}

The literature on PI-IBS, SIBO, the relationship between gut microbiota and GI sensorimotor functions, and the potential for probiotics and antibiotics to alter these functions and to improve some of the symptoms of IBS, taken together, provide strong evidence in support of a major role for the gut microbiota in the pathogenesis of IBS. This concept represents a potential paradigm shift in our understanding of the underlying mechanism (for at least a subset of patients with IBS) from that of IBS as an entirely psychosomatic disorder to that of a more organic disorder related to an altered gut microbiota and low-grade inflammation. This could, ultimately, lead to a potential change in the management of IBS to strategies that alter the gut microbiota and inflammation.

\section{References}

[1] K. Ponnusamy, J. N. Choi, J. Kim, S.-Y. Lee, and C. H. Lee, "Microbial community and metabolomic comparison of irritable bowel syndrome faeces," Journal of Medical Microbiology, vol. 60, no. 6, pp. 817-827, 2011.

[2] E. M. M. Quigley and R. Quera, "Small intestinal bacterial overgrowth: roles of antibiotics, prebiotics, and probiotics," Gastroenterology, vol. 130, no. 2, supplement 1, pp. S78-S90, 2006.

[3] S. Prakash, L. Rodes, M. Coussa-Charley et al., "Gut microbiota: next frontier in understanding human health and development of biotherapeutics," Biologics, vol. 5, pp. 71-86, 2011.

[4] I. Sekirov, S. L. Russell, L. Caetano M Antunes, and B. B. Finlay, "Gut microbiota in health and disease," Physiological Reviews, vol. 90, no. 3, pp. 859-904, 2010.

[5] M. Carrara, S. Desideri, M. Azzurro et al., "Small intestine bacterial overgrowth in patients with irritable bowel syndrome," European Review for Medical and Pharmacological Sciences, vol. 12, no. 3, pp. 197-202, 2008.

[6] E. Malinen, T. Rinttilä, K. Kajander et al., "Analysis of the fecal microbiota of irritable bowel syndrome patients and healthy controls with real-time PCR," American Journal of Gastroenterology, vol. 100, no. 2, pp. 373-382, 2005.
[7] A. S. Neish, "Microbes in gastrointestinal health and disease," Gastroenterology, vol. 136, no. 1, pp. 65-80, 2009.

[8] E. M. Quigley, "Do patients with functional gastrointestinal disorders have an altered gut flora?" Therapeutic Advances in Gastroenterology, vol. 2, no. 4, pp. 23-30, 2009.

[9] J. M. Park, M. G. Choi, Y. K. Cho et al., "Functional gastrointestinal disorders diagnosed by Rome III questionnaire in Korea," Journal of Neurogastroenterology and Motility, vol. 17, no. 3, pp. 279-286, 2011.

[10] M. Teo, S. Chung, L. Chitti et al., "Small bowel bacterial overgrowth is a common cause of chronic diarrhea," Journal of Gastroenterology and Hepatology, vol. 19, no. 8, pp. 904909, 2004.

[11] I. Posserud, A. Ersryd, and M. Simrén, "Functional findings in irritable bowel syndrome," World Journal of Gastroenterology, vol. 12, no. 19, pp. 2830-2838, 2006.

[12] H. Park, "The role of small intestinal bacterial overgrowth in the pathophysiology of irritable bowel syndrome," Journal of Neurogastroenterology and Motility, vol. 16, no. 1, pp. 3-4, 2010.

[13] J. Bures, J. Cyrany, D. Kohoutova et al., "Small intestinal bacterial overgrowth syndrome," World Journal of Gastroenterology, vol. 16, no. 24, pp. 2978-2990, 2010.

[14] U. C. Ghoshal, H. Park, and K. A. Gwee, "Bugs and irritable bowel syndrome: the good, the bad and the ugly," Journal of Gastroenterology and Hepatology, vol. 25, no. 2, pp. 244-251, 2010.

[15] M. Simrén and P. O. Stotzer, "Use and abuse of hydrogen breath tests," Gut, vol. 55, no. 3, pp. 297-303, 2006.

[16] A. M. Scanu, T. J. Bull, S. Cannas et al., "Mycobacterium avium subspecies paratuberculosis infection in cases of irritable bowel syndrome and comparison with Crohn's disease and Johne's disease: common neural and immune pathogenicities," Journal of Clinical Microbiology, vol. 45, no. 12, pp. 3883-3890, 2007.

[17] E. Malinen, L. Krogius-Kurikka, A. Lyra et al., "Association of symptoms with gastrointestinal microbiota in irritable bowel syndrome," World Journal of Gastroenterology, vol. 16, no. 36, pp. 4532-4540, 2010.

[18] A. Kassinen, L. Krogius-Kurikka, H. Mäkivuokko et al., "The fecal microbiota of irritable Bowel syndrome patients differs significantly from that of healthy subjects," Gastroenterology, vol. 133, no. 1, pp. 24-33, 2007.

[19] I. M. Carroll, Y. H. Chang, J. Park, R. B. Sartor, and Y. Ringel, "Luminal and mucosal-associated intestinal microbiota in patients with diarrhea-predominant irritable bowel syndrome," Gut Pathogens, vol. 2, no. 1, 2010.

[20] A. Lyra, L. Krogius-Kurikka, J. Nikkilä et al., "Effect of a multispecies probiotic supplement on quantity of irritable bowel syndrome-related intestinal microbial phylotypes," BMC Gastroenterology, vol. 10, p. 110, 2010.

[21] W. G. Thompson, "The road to Rome," Gastroenterology, vol. 130, no. 5, pp. 1552-1556, 2006.

[22] G. C. Parkes, J. Brostoff, K. Whelan, and J. D. Sanderson, "Gastrointestinal microbiota in irritable bowel syndrome: their role in its pathogenesis and treatment," American Journal of Gastroenterology, vol. 103, no. 6, pp. 1557-1567, 2008.

[23] G. K. Makharia, A. K. Verma, R. Amarchand et al., "Prevalence of irritable bowel syndrome: a community based study from northern India," Journal of Neurogastroenterology and Motility, vol. 17, no. 1, pp. 82-87, 2011.

[24] U. C. Ghoshal, P. Abraham, C. Bhatt et al., "Epidemiological and clinical profile of irritable bowel syndrome in India: 
report of the Indian Society of Gastroenterology Task Force," Indian Journal of Gastroenterology, vol. 27, no. 1, pp. 22-28, 2008.

[25] K. A. Gwee, C. L. Lu, and U. C. Ghoshal, "Epidemiology of irritable bowel syndrome in Asia: something old, something new, something borrowed," Journal of Gastroenterology and Hepatology, vol. 24, no. 10, pp. 1601-1607, 2009.

[26] L. Öhman and M. Simrén, "New insights into the pathogenesis and pathophysiology of irritable bowel syndrome," Digestive and Liver Disease, vol. 39, no. 3, pp. 201-215, 2007.

[27] T. Karantanos, T. Markoutsaki, M. Gazouli et al., "Current insights in to the pathophysiology of irritable Bowel syndrome," Gut Pathogens, vol. 2, no. 1, p. 3, 2010.

[28] E. K. Brint, J. MacSharry, A. Fanning, F. Shanahan, and E. M.M. Quigley, "Differential expression of toll-like receptors in patients with irritable bowel syndrome," American Journal of Gastroenterology, vol. 106, no. 2, pp. 329-336, 2011.

[29] D. A. Drossman, "The functional gastrointestinal disorders and the Rome III process," Gastroenterology, vol. 130, no. 5, pp. 1377-1390, 2006.

[30] B. J. Lee and Y. T. Bak, "Irritable bowel syndrome, gut microbiota and probiotics," Journal of Neurogastroenterology and Motility, vol. 17, no. 3, pp. 252-266, 2011.

[31] J. E. Kellow, F. Azpiroz, M. Delvaux et al., "Applied principles of neurogastroenterology: physiology/motility sensation," Gastroenterology, vol. 130, no. 5, pp. 1412-1420, 2006.

[32] T. Rinttilä, A. Lyra, L. Krogius-Kurikka, and A. Palva, "Realtime PCR analysis of enteric pathogens from fecal samples of irritable bowel syndrome subjects," Gut Pathogens, vol. 3, no. $1,2011$.

[33] A. P.M. Kerckhoffs, K. Ben-Amor, M. Samsom et al., "Molecular analysis of faecal and duodenal samples reveals significantly higher prevalence and numbers of Pseudomonas aeruginosa in irritable bowel syndrome," Journal of Medical Microbiology, vol. 60, no. 2, pp. 236-245, 2011.

[34] M. Rajilić-Stojanović, E. Biagi, H. G.H.J. Heilig et al., "Global and deep molecular analysis of microbiota signatures in fecal samples from patients with irritable bowel syndrome," Gastroenterology, vol. 141, no. 5, pp. 1792-1801, 2011.

[35] D. M. Saulnier, K. Riehle, T. -A. Mistretta et al., "Gastrointestinal microbiome signatures of pediatric patients with irritable bowel syndrome," Gastroenterology, vol. 141, no. 5, pp. 1782-1791, 2011.

[36] A. Salonen, W. M. De Vos, and A. Palva, "Gastrointestinal microbiota in irritable bowel syndrome: present state and perspectives," Microbiology, vol. 156, no. 11, pp. 3205-3215, 2010.

[37] G. Le Gall, S. O. Noor, K. Ridgway et al., "Metabolomics of fecal extracts detects altered metabolic activity of gut microbiota in ulcerative colitis and irritable bowel syndrome," Journal of Proteome Research, vol. 10, no. 9, pp. 4208-4218, 2011.

[38] S. Vanner, "The small intestinal bacterial overgrowth. Irritable bowel syndrome hypothesis: implications for treatment," Gut, vol. 57, no. 9, pp. 1315-1321, 2008.

[39] A. W. DuPont, "Postinfectious irritable bowel syndrome," Clinical Infectious Diseases, vol. 46, no. 4, pp. 594-599, 2008.

[40] S. R. Jee, W. Morales, K. Low et al., "ICC density predicts bacterial overgrowth in a rat model of post-infectious IBS," World Journal of Gastroenterology, vol. 16, no. 29, pp. 36803686, 2010.

[41] J. K. Marshall, M. Thabane, A. X. Garg, W. F. Clark, M. Salvadori, and S. M. Collins, "Incidence and epidemiology of irritable Bowel syndrome after a large waterborne outbreak of bacterial dysentery," Gastroenterology, vol. 131, no. 2, pp. 445-450, 2006.

[42] S. D. Parry, R. Stansfield, D. Jelley et al., "Does bacterial gastroenteritis predispose people to functional gastrointestinal disorders? A prospective, community-based, case-control study," American Journal of Gastroenterology, vol. 98, no. 9, pp. 1970-1975, 2003.

[43] K. A. Gwee, J. C. Graham, M. W. McKendrick et al., "Psychometric scores and persistence of irritable bowel after infectious diarrhoea," Lancet, vol. 347, no. 8995, pp. 150-153, 1996.

[44] M. Thabane, D. T. Kottachchi, and J. K. Marshall, "Systematic review and meta-analysis: the incidence and prognosis of post-infectious irritable bowel syndrome," Alimentary Pharmacology and Therapeutics, vol. 26, no. 4, pp. 535-544, 2007.

[45] H. A. Halvorson, C. D. Schlett, M. S. Riddle, and M. AlHaddad, "Postinfectious irritable bowel syndrome-a metaanalysis," American Journal of Gastroenterology, vol. 101, no. 8, pp. 1894-1942, 2006.

[46] H. L. DuPont, G. Galler, F. Garcia-Torres, A. W. DuPont, A. Greisinger, and Z. D. Jiang, "Travel and travelers' diarrhea in patients with irritable bowel syndrome," American Journal of Tropical Medicine and Hygiene, vol. 82, no. 2, pp. 301-305, 2010.

[47] M. Thabane and J. K. Marshall, "Post-infectious irritable bowel syndrome," World Journal of Gastroenterology, vol. 15, no. 29, pp. 3591-3596, 2009.

[48] S. K. Sarna, "Lessons learnt from post-infectious IBS," Frontiers in Physiology, vol. 2, p. 49, 2011.

[49] A. Villani, M. Lemire, M. Thabane et al., "Genetic risk factors for post-infectious irritable Bowel syndrome following a waterborne outbreak of gastroenteritis," Gastroenterology, vol. 138, no. 4, pp. 1502-1513, 2010.

[50] S. P. Dunlop, J. Hebden, E. Campbell et al., "Abnormal intestinal permeability in subgroups of diarrhea-predominant irritable bowel syndromes," American Journal of Gastroenterology, vol. 101, no. 6, pp. 1288-1294, 2006.

[51] T. Piche, G. Barbara, P. Aubert et al., "Impaired Intestinal barrier integrity in the colon of patients with irritable bowel syndrome: involvement of soluble mediators," Gut, vol. 58, no. 2, pp. 196-201, 2009.

[52] K. J. Lee, Y. B. Kim, J. H. Kim, H. C. Kwon, D. K. Kim, and S. W. Cho, "The alteration of enterochromaffin cell, mast cell, and lamina propria $\mathrm{T}$ lymphocyte numbers in irritable bowel syndrome and its relationship with psychological factors," Journal of Gastroenterology and Hepatology, vol. 23, no. 11, pp. 1689-1694, 2008.

[53] K. A. Gwee, S. M. Collins, N. W. Read et al., "Increased rectal mucosal expression of interleukin $1 \beta$ in recently acquired post-infectious irritable bowel syndrome," Gut, vol. 52, no. 4, pp. 523-526, 2003.

[54] K. J. Lee and J. Tack, "Altered intestinal microbiota in irritable bowel syndrome," Neurogastroenterology and Motility, vol. 22, no. 5, pp. 493-498, 2010.

[55] J. Chow, S. M. Lee, Y. Shen, A. Khosravi, and S. K. Mazmanian, "Host-bacterial symbiosis in health and disease," Advances in Immunology, vol. 107, no. C, pp. 243-274, 2010.

[56] I. Posserud, P. O. Stotzer, E. S. Björnsson, H. Abrahamsson, and M. Simrén, "Small intestinal bacterial overgrowth in patients with irritable bowel syndrome," Gut, vol. 56, no. 6, pp. 802-808, 2007.

[57] A. Gasbarrini, E. C. Lauritano, M. Gabrielli et al., "Small intestinal bacterial overgrowth: diagnosis and treatment," Digestive Diseases, vol. 25, no. 3, pp. 237-240, 2007. 
[58] U. C. Ghoshal, S. Kumar, M. Mehrotra et al., "Frequency of small intestinal bacterial overgrowth in patients with irritable bowel syndrome and chronic non-specific diarrhea," Journal Neurogastroenterology and Motility, vol. 16, no. 1, pp. 40-46, 2010.

[59] U. C. Ghoshal, "How to interpret hydrogen breath tests," Journal of Neurogastroenterology and Motility, vol. 17, no. 3, pp. 312-317, 2011.

[60] S. Chandra, U. Dutta, M. T. Noor et al., "Endoscopic jejunal biopsy culture: a simple and effective method to study jejunal microflora," Indian Journal of Gastroenterology, pp. 1-5, 2011.

[61] M. Pimentel, E. J. Chow, and H. C. Lin, "Normalization of lactulose breath testing correlates with symptom improvement in irritable bowel syndrome: a double-blind, randomized, placebo-controlled study," American Journal of Gastroenterology, vol. 98, no. 2, pp. 412-419, 2003.

[62] U. C. Ghoshal, U. Ghoshal, K. Das, and A. Misra, "Utility of hydrogen breath tests in diagnosis of small intestinal bacterial overgrowth in malabsorption syndrome, and its relationship with orocecal transit time," Indian Journal of Gastroenterology, vol. 25, no. 1, pp. 6-10, 2006.

[63] H. K. Berthold, P. Schober, C. Scheurlen et al., "Use of the lactose-[13C] ureide breath test for diagnosis of small bowel bacterial overgrowth: comparison to the glucose hydrogen breath test," Journal of Gastroenterology, vol. 44, no. 9, pp. 944-951, 2009.

[64] S. H. Kyoung, W. K. Hyoun, P. I. Jong et al., "Effect of probiotics on symptoms in Korean adults with irritable bowel syndrome," Gut and Liver, vol. 3, no. 2, pp. 101-107, 2009.

[65] S. J. Lewis, S. Franco, G. Young, and S. J. D. O'Keefe, "Altered bowel function and duodenal bacterial overgrowth in patients treated with omeprazole," Alimentary Pharmacology and Therapeutics, vol. 10, no. 4, pp. 557-561, 1996.

[66] C. Williams and K. E. L. McColl, "Proton pump inhibitors and bacterial overgrowth," Alimentary Pharmacology and Therapeutics, vol. 23, no. 1, pp. 3-10, 2006.

[67] X. Fan and J. H. Sellin, "Small intestinal bacterial overgrowth, bile acid malabsorption and gluten intolerance as possible causes of chronic watery diarrhoea," Alimentary Pharmacology and Therapeutics, vol. 29, no. 10, pp. 1069-1077, 2009.

[68] B. M. R. Spiegel, W. D. Chey, and L. Chang, "Bacterial overgrowth and irritable bowel syndrome: unifying hypothesis or a spurious consequence of proton pump inhibitors?" American Journal of Gastroenterology, vol. 103, no. 12, pp. 2972-2976, 2008.

[69] E. J. Schiffrin and S. Blum, "Interactions between the microbiota and the intestinal mucosa," European Journal of Clinical Nutrition, vol. 56, supplement 3, pp. S60-S64, 2002.

[70] T. Tanoue, Y. Umesaki, and K. Honda, "Immune responses to gut microbiota-commensals and pathogens," Gut Microbes, vol. 1, no. 4, pp. 224-233, 2010.

[71] S. Vaishnava, C. L. Behrendt, A. S. Ismail, L. Eckmann, and L. V. Hooper, "Paneth cells directly sense gut commensals and maintain homeostasis at the intestinal host-microbial interface," Proceedings of the National Academy of Sciences of the United States of America, vol. 105, no. 52, pp. 2085820863, 2008.

[72] C. L. Ohland and W. K. MacNaughton, "Probiotic bacteria and intestinal epithelial barrier function," American Journal of Physiology, Gastrointestinal and Liver Physiology, vol. 298, no. 6, pp. G807-G819, 2010.

[73] R. C. Anderson, A. L. Cookson, W. C. McNabb et al., "Lactobacillus plantarum MB452 enhances the function of the intestinal barrier by increasing the expression levels of genes involved in tight junction formation," BMC Microbiology, vol. 10, article no. 316, 2010.

[74] Z. H. Liu, T. Y. Shen, P. Zhang, Y. L. Ma, M. P. Moyer, and H. L. Qin, "Protective effects of Lactobacillus plantarum against epithelial barrier dysfunction of human colon cell line NCM460," World Journal of Gastroenterology, vol. 16, no. 45, pp. 5759-5765, 2010.

[75] Q. Zhou, W. W. Souba, C. M. Croce, and G. N. Verne, "MicroRNA-29a regulates intestinal membrane permeability in patients with irritable bowel syndrome," Gut, vol. 59, no. 6, pp. 775-784, 2010.

[76] H. L. B. M. Klaasen, P. J. Van der Heijden, W. Stok et al., "Apathogenic, intestinal, segmented, filamentous bacteria stimulate the mucosal immune system of mice," Infection and Immunity, vol. 61, no. 1, pp. 303-306, 1993.

[77] S. K. Mazmanian, J. L. Round, and D. L. Kasper, "A microbial symbiosis factor prevents intestinal inflammatory disease," Nature, vol. 453, no. 7195, pp. 620-625, 2008.

[78] P. Veiga, C. A. Gallini, C. Beal et al., "Bifidobacterium animalis subsp. lactis fermented milk product reduces inflammation by altering a niche for colitogenic microbes," Proceedings of the National Academy of Sciences of the United States of America, vol. 107, no. 42, pp. 18132-18137, 2010.

[79] V. Gaboriau-Routhiau, S. Rakotobe, E. Lécuyer et al., "The key role of segmented filamentous bacteria in the coordinated maturation of gut helper T cell responses," Immunity, vol. 31, no. 4, pp. 677-689, 2009.

[80] T. Liebregts, B. Adam, C. Bredack et al., "Immune activation in patients With irritable Bowel syndrome," Gastroenterology, vol. 132, no. 3, pp. 913-920, 2007.

[81] L. Ohman, S. Isaksson, A. C. Lindmark et al., "T-cell activation in patients with irritable bowel syndrome," American Journal of Gastroenterology, vol. 104, no. 5, pp. 1205-1212, 2009.

[82] V. Z. Rocha and E. J. Folco, "Inflammatory concepts of obesity," International Journal of Inflammation, vol. 2011, Article ID 529061, 14 pages, 2011.

[83] N. Holmen, S. Isaksson, M. Simren et al., "CD4 $4^{+} \mathrm{CD} 25^{+}$ regulatory $\mathrm{T}$ cells in irritable bowel syndrome patients," Neurogastroenterology \& Motility, vol. 19, no. 2, pp. 119-25, 2007.

[84] H. C. Lin and K. Al-Khatib, "Immune activation and gut microbes in irritable bowel syndrome," Gut and Liver, vol. 3, no. 1, pp. 14-19, 2009.

[85] G. Barbara, "Toll-like receptor expression in irritable bowel syndrome: on the alert for a microbial threat," American Journal of Gastroenterology, vol. 106, no. 2, pp. 337-339, 2011.

[86] C. O’Mahony, P. Scully, D. O’Mahony et al., "Commensalinduced regulatory $\mathrm{T}$ cells mediate protection against pathogen-stimulated NF- $\kappa$ B activation," PLoS Pathogens, vol. 4, no. 8, Article ID e1000112, 2008.

[87] O'Sullivan, Clayton, Breslin et al., "Increased mast cells in the irritable bowel syndrome," Neurogastroenterology and Motility, vol. 12, no. 5, pp. 449-457, 2000.

[88] B. E. Lacy, K. Weiser, and R. De Lee, "The treatment of irritable bowel syndrome," Therapeutic Advances in Gastroenterology, vol. 2, no. 4, pp. 221-238, 2009.

[89] W. D. Chey, M. Maneerattaporn, and R. Saad, "Pharmacologic and complementary and alternative medicine therapies for irritable bowel syndrome," Gut and Liver, vol. 5, no. 3, pp. 253-266, 2011.

[90] L. O’Mahony, J. Mccarthy, P. Kelly et al., "Lactobacillus and Bifidobacterium in irritable bowel syndrome: symptom 
responses and relationship to cytokine profiles," Gastroenterology, vol. 128, no. 3, pp. 541-551, 2005.

[91] T. Steer, H. Carpenter, K. Tuohy, and G. R. Gibson, "Perspectives on the role of the human gut microbiota and its modulation by pro- and prebiotics," Nutrition Research Reviews, vol. 13, no. 2, pp. 229-254, 2000.

[92] H. J. Kim, M. Camilleri, S. McKinzie et al., "A randomized controlled trial of a probiotic, VSL\#3, on gut transit and symptoms in diarrhoea-predominant irritable bowel syndrome," Alimentary Pharmacology and Therapeutics, vol. 17, no. 7, pp. 895-904, 2003.

[93] H. J. Kim, M. I. Vazquez Roque, M. Camilleri et al., "A randomized controlled trial of a probiotic combination VSL\# 3 and placebo in irritable bowel syndrome with bloating," Neurogastroenterology and Motility, vol. 17, no. 5, pp. 687696, 2005.

[94] G. A. Preidis and J. Versalovic, "Targeting the human microbiome with antibiotics, probiotics, and prebiotics: gastroenterology enters the metagenomics era," Gastroenterology, vol. 136, no. 6, pp. 2015-2031, 2009.

[95] J. C. Y. Wu, "Complementary and alternative medicine modalities for the treatment of irritable bowel syndrome: facts or myths?" Gastroenterology and Hepatology, vol. 6, no. 11, pp. 705-711, 2010.

[96] D. B. A. Silk, A. Davis, J. Vulevic, G. Tzortzis, and G. R. Gibson, "The effects of a trans-galactooligosaccharide prebiotic on faecal microbiota and symptoms in irritable bowel syndrome," Alimentary Pharmacology and Therapeutics, vol. 29, no. 5, pp. 508-518, 2009.

[97] J. H. Cummings, G. T. Macfarlane, and H. N. Englyst, "Prebiotic digestion and fermentation," American Journal of Clinical Nutrition, vol. 73, no. 2, supplement, pp. 415S-420S, 2001.

[98] J. Schrezenmeir and M. De Vrese, "Probiotics, prebiotics, and synbiotics - Approaching a definition," American Journal of Clinical Nutrition, vol. 73, no. 2, pp. 361S-364S, 2001.

[99] S. Gupta, V. Kapoor, and B. Kapoor, "Itopride: a novel prokinetic agent,” Pharmacology, vol. 6, no. 2, pp. 106-108, 2004.

[100] P. Paré, R. Bridges, M. C. Champion et al., "Recommendations on chronic constipation (including constipation associated with irrtable bowel syndrome) treatment," Canadian Journal of Gastroenterology, vol. 21, supplement B, pp. 3B22B, 2007.

[101] D. Lesbros-Pantoflickova, P. Michetti, M. Fried, C. Beglinger, and A. L. Blum, "Meta-analysis: the treatment of irritable bowel syndrome," Alimentary Pharmacology and Therapeutics, vol. 20, no. 11-12, pp. 1253-1269, 2004.

[102] C. L. Frissora and B. D. Cash, "The role of antibiotics vs. conventional pharmacotherapy in treating symptoms of irritable bowel syndrome," Alimentary Pharmacology and Therapeutics, vol. 25, no. 11, pp. 1271-1281, 2007.

[103] K. Tillisch and L. Chang, "Diagnosis and treatment of irritable bowel syndrome: state of the art," Current Gastroenterology Reports, vol. 7, no. 4, pp. 249-256, 2005.

[104] H. C. Lin, "Small intestinal bacterial overgrowth: a framework for understanding irritable bowel syndrome," Journal of the American Medical Association, vol. 292, no. 7, pp. 852$858,2004$.

[105] M. Pimentel, A. Lembo, W. D. Chey et al., "Rifaximin therapy for patients with irritable bowel syndrome without constipation," New England Journal of Medicine, vol. 364, no. 1, pp. 22-32, 2011.
[106] J. Maukonen, R. Satokari, J. Mättö, H. Söderlund, T. MattilaSandholm, and M. Saarela, "Prevalence and temporal stability of selected clostridial groups in irritable bowel syndrome in relation to predominant faecal bacteria," Journal of Medical Microbiology, vol. 55, no. 5, pp. 625-633, 2006.

[107] A. P. M. Kerckhoffs, M. Samsom, M. E. van der Rest et al., "Lower Bifidobacteria counts in both duodenal mucosaassociated and fecal microbiota in irritable bowel syndrome patients," World Journal of Gastroenterology, vol. 15, no. 23, pp. 2887-2892, 2009.

[108] B. M. Sobieszczańska, J. Osek, D. Waśko-Czopnik, E. Dworniczek, and K. Jermakow, "Association of enteroaggregative Escherichia coli with irritable bowel syndrome," Clinical Microbiology and Infection, vol. 13, no. 4, pp. 404-407, 2007.

[109] A. Lyra, T. Rinttilä, J. Nikkilä et al., "Diarrhoea-predominant irritable bowel syndrome distinguishable by 16S rRNA gene phylotype quantification," World Journal of Gastroenterology, vol. 15, no. 47, pp. 5936-5945, 2009.

[110] L. Krogius-Kurikka, A. Lyra, E. Malinen et al., "Microbial community analysis reveals high level phylogenetic alterations in the overall gastrointestinal microbiota of diarrhoeapredominant irritable bowel syndrome sufferers," BMC Gastroenterology, vol. 9, article no. 95, 2009.

[111] J. M. Si, Y. C. Yu, Y. J. Fan, and S. J. Chen, "Intestinal microecology and quality of life in irritable bowel syndrome patients," World Journal of Gastroenterology, vol. 10, no. 12, pp. 1802-1805, 2004.

[112] C. Codling, L. O’Mahony, F. Shanahan, E. M. M. Quigley, and J. R. Marchesi, "A molecular analysis of fecal and mucosal bacterial communities in irritable bowel syndrome," Digestive Diseases and Sciences, vol. 55, no. 2, pp. 392-397, 2010.

[113] C. Tana, Y. Umesaki, A. Imaoka, T. Handa, M. Kanazawa, and S. Fukudo, "Altered profiles of intestinal microbiota and organic acids may be the origin of symptoms in irritable bowel syndrome," Neurogastroenterology and Motility, vol. 22, no. 5, pp. 512-e115, 2010.

[114] S.C. Ng, E. Lam, T. Y. Lam et al., "Pyrosequencing alalysis reveals high level phylogenetic alterations in mucosalassociated intestinal microbiota of patients with irritable bowel syndrome," Gut, vol. 60, 2011.

[115] J. S. Park, J. H. Yu, H. C. Lim et al., "Usefulness of lactulose breath test for the prediction of small intestinal bacterial overgrowth in irritable bowel syndrome," The Korean Journal of Gastroenterology, vol. 56, no. 4, pp. 242-248, 2010.

[116] E. Scarpellini, V. Giorgio, M. Gabrielli et al., "Prevalence of small intestinal bacterial overgrowth in children with irritable Bowel syndrome: a case-control study," Journal of Pediatrics, vol. 155, no. 3, pp. 416-420, 2009.

[117] N. S. Mann and M. Limoges-Gonzales, "The prevalence of small intestinal bacterial overgrowth in irritable bowel syndrome," Hepato-Gastroenterology, vol. 56, no. 91-92, pp. 718-721, 2009.

[118] G. Nucera, M. Gabrielli, A. Lupascu et al., "Abnormal breath tests to lactose, fructose and sorbitol in irritable bowel syndrome may be explained by small intestinal bacterial overgrowth," Alimentary Pharmacology and Therapeutics, vol. 21, no. 11, pp. 1391-1395, 2005.

[119] S. Sachdeva, A. K. Rawat, R. S. Reddy, and A. S. Puri, "Small intestinal bacterial overgrowth (SIBO) in irritable bowel syndrome: frequency and predictors," Journal of Gastroenterology and Hepatology, vol. 26, supplement 3, pp. 135-138, 2011.

[120] S. C. Reddymasu, S. Sostarich, and R. W. McCallum, "Small intestinal bacterial overgrowth in irritable bowel syndrome: 
are there any predictors?” BMC Gastroenterology, vol. 10, article no. 23, 2010.

[121] A. C. Ford, B. M.R. Spiegel, N. J. Talley, and P. Moayyedi, "Small intestinal bacterial overgrowth in irritable Bowel syndrome: systematic review and meta-analysis," Clinical Gastroenterology and Hepatology, vol. 7, no. 12, pp. 12791286, 2009.

[122] A. Parodi, P. Dulbecco, E. Savarino et al., "Positive glucose breath testing is more prevalent in patients with IBS-like symptoms compared with controls of similar age and gender distribution," Journal of Clinical Gastroenterology, vol. 43, no. 10, pp. 962-966, 2009.

[123] S. V. Rana, S. K. Sinha, A. Sikander, D. K. Bhasin, and K. Singh, "Study of small intestinal bacterial overgrowth in North Indian patients with irritable bowel syndrome: a case control study," Tropical Gastroenterology, vol. 29, no. 1, pp. 23-25, 2008.

[124] M. Majewski and R. W. McCallum, "Results of small intestinal bacterial overgrowth testing in irritable bowel syndrome patients: clinical profiles and effects of antibiotic trial," Advances in medical sciences, vol. 52, pp. 139-142, 2007.

[125] L. Cuoco and M. Salvagnini, "Small intestine bacterial overgrowth in irritable bowel syndrome: a retrospective study with rifaximin," Minerva Gastroenterologica e Dietologica, vol. 52, no. 1, pp. 89-95, 2006.

[126] A. Lupascu, M. Gabrielli, E. C. Lauritano et al., "Hydrogen glucose breath test to detect small intestinal bacterial overgrowth: a prevalence case-control study in irritable bowel syndrome," Alimentary Pharmacology and Therapeutics, vol. 22, no. 11-12, pp. 1157-1160, 2005.

[127] M. Grover, M. Kanazawa, O. S. Palsson et al., "Small intestinal bacterial overgrowth in irritable bowel syndrome: association with colon motility, bowel symptoms, and psychological distress," Neurogastroenterology and Motility, vol. 20, no. 9, pp. 998-1008, 2008. 


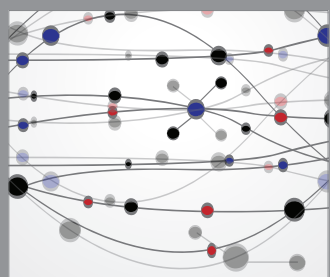

The Scientific World Journal
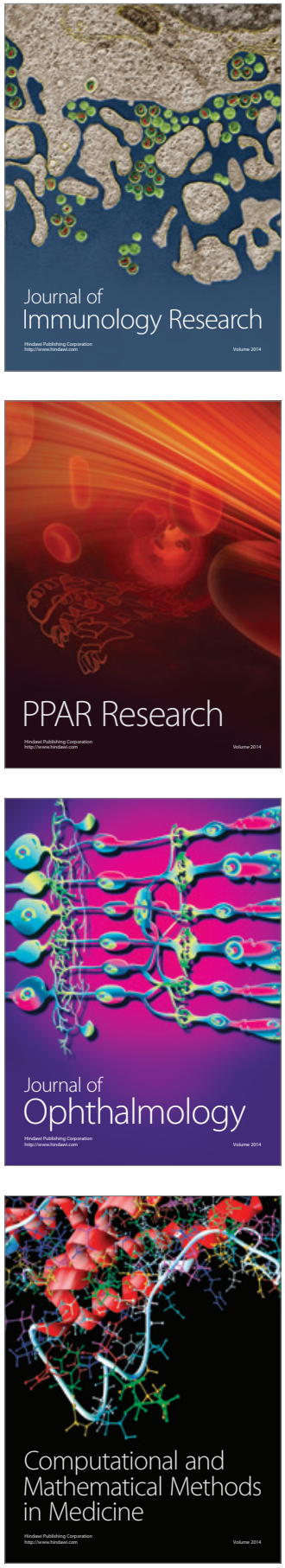

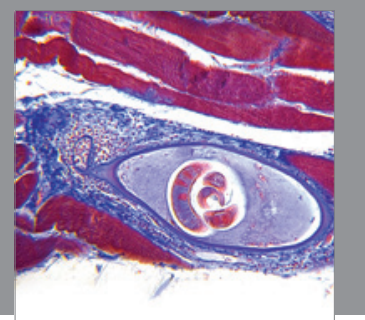

Gastroenterology

Research and Practice
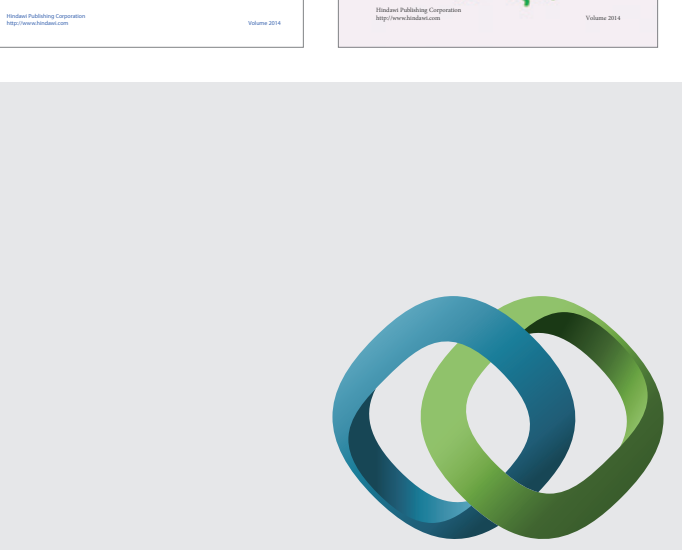

\section{Hindawi}

Submit your manuscripts at

http://www.hindawi.com
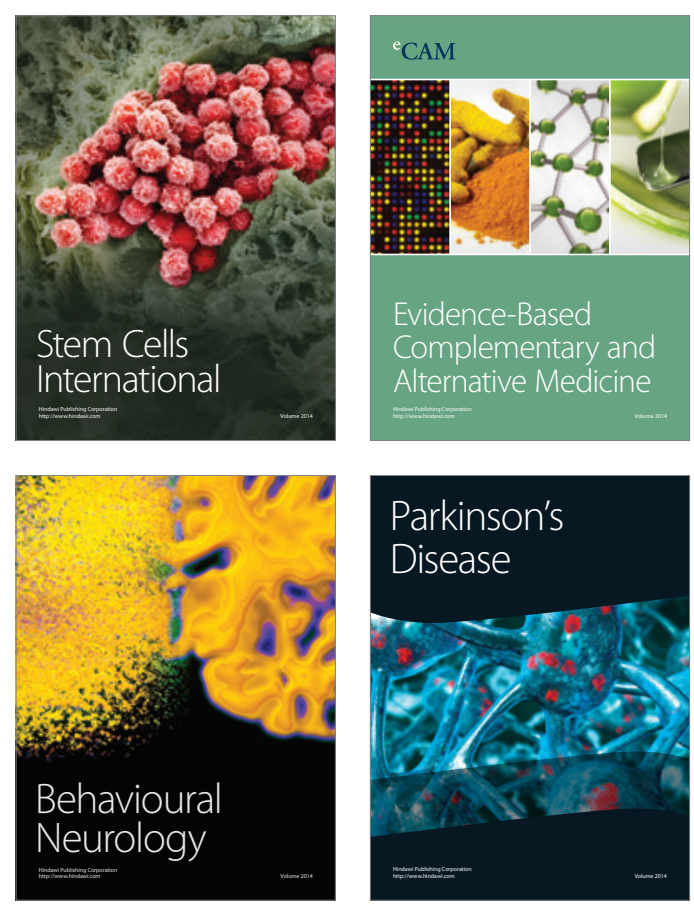

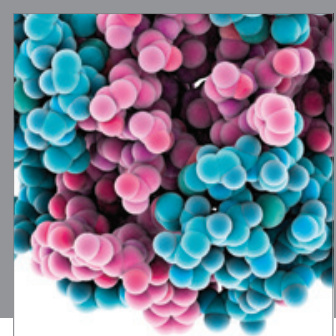

Journal of
Diabetes Research

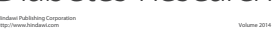

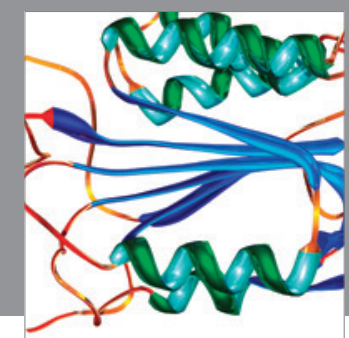

Disease Markers
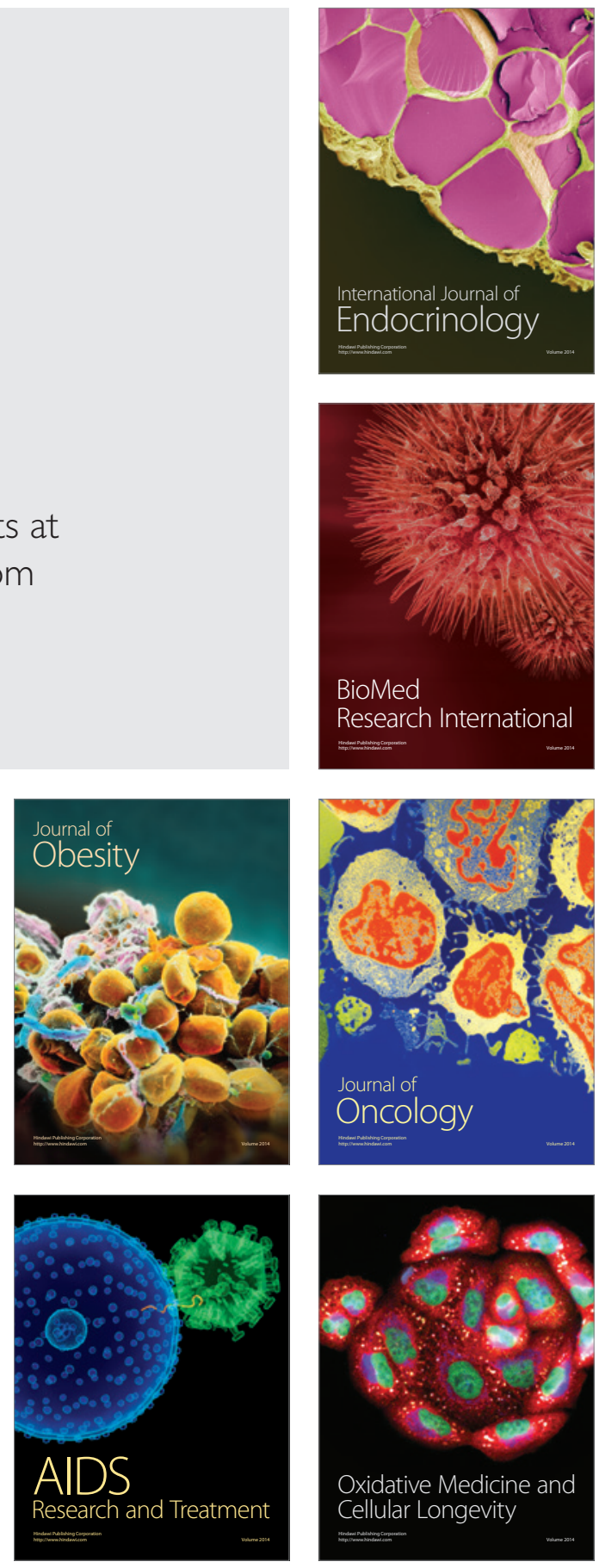